\title{
Evolution of the Residual Risk of Transmitting HIV, HCV and HBV in the Blood Transfusion from 1998 to 2009 in Cote d'Ivoire
}

\author{
Adeoti $\mathrm{FM}^{1 *}$, Oyourou $\mathrm{AO}^{2}$, Sirancy- Bogui $\mathrm{L}^{3}$, Konate $\mathrm{S}^{4}$ and Sess $\mathrm{ED}^{5}$ \\ ${ }^{1}$ Head of Clinical Biochemistry Unit, Central Laboratory Specialty: Physician, Medical Biochemistry, Yopougon Teaching Hospital, Abidjan, Cote d'Ivoire \\ ${ }^{2}$ Service Quality, National Institute of Public Health Specialty: Pharmacist, Quality Management, Abidjan, Cote d'Ivoire \\ ${ }^{3}$ Head of Blood Center Laboratory, National Blood Transfusion Center Specialty: Physician, Immunologist and Hematologist, Abidjan, Cote d'Ivoire \\ ${ }^{4}$ Director of the National Blood Transfusion Centre of Côte d'Ivoire Specialty: Physician, Transfusion Medicine, National Blood Transfusion Center, Abidjan, Cote d'Ivoire \\ ${ }^{5}$ Director of the Laboratory of Medical Biochemistry, Specialty: Physician, Medical Biochemistry, Cocody Teaching Hospital, Abidjan, Cote d'Ivoire
}

\begin{abstract}
Prevention of viral contamination of blood from blood bags collected remains a concern finds strategies traceability of blood products and blood safety in Côte d'Ivoire. Thus, the authors have estimated the residual risk of transmission of human immunodeficiency virus (HIV), Hepatitis B virus (HBV) and Hepatitis C (HCV) among blood donors in four periods of three years, 1998-2000, 2001-2003, 2004-2006, 2007-2009 from data collected at the blood establishments in the national territory.

The determination of HIV antibodies against the hepatitis $C$ virus and the surface antigen of hepatitis $B(\mathrm{HBs} A g)$ were carried out by immuno-enzymatic techniques plate (ELISA) associated with the residual risk assessment.

The results showed a gradual decrease of the residual risk of HIV to be the lowest in the period 2007-2009 with 12 per 100000 or 1 per 8333 donations. Residual risk of hepatitis $B$ and $C$ have known an increase during the different periods to be respectively 219 to 100000 or 1457 and 1180 per 100000 or 1 per 85 donations over the period 2007-2009. The residual risk of HCV is 98 times higher than HIV and 18 times that of hepatitis B.
\end{abstract}

These results show that efforts must be continued in the steps of donor selection, confirmation of screening test for viral contamination and assessment of residual risk of viral transmission during blood transfusion

Keywords: Residual risk; Blood transfusion; HIV; Hepatitis C; Hepatitis B

\section{Introduction}

Blood safety in Africa and particularly in Côte d'Ivoire, is a public health problem that led to the adoption of strict measures both on recruitment and selection of blood donors, the biological qualification of the gift which, thanks to a series of systematic screening, to remove the infection and gifts to exclude donors with these infections.

Serologic screening is primarily to identify indicators of pathogens in the body, means of different tests. It allows a quantitative and qualitative approach. It is used as a diagnostic tool, as a screening tool (AIDS, Hepatitis, etc.) and as an epidemiological tool.

So today, the risk of infection through transfusion of the AIDS virus as hepatitis B virus (HBV) and C (HCV) has decreased significantly through the application of preventive measures and to improve the sensitivity detection reagents sérologique [1]. However, there remains a residual risk, very low, but persistent and this, despite the measures for donor selection and screening of biomarkers.

This risk can have several causes related to error handling is very weak [2], a variant not recognized by certain reagents such as HIV1 group $\mathrm{O}$ [3], a chronic carrier of the virus that has not developed anticorps [4], a subject recently infected that would give his blood before the markers of infection are apparus $[5,6]$.

In general, it is recognized that post-transfusion residual risk is mainly related to the window period, represented by blood donations made during the period between infection and the appearance of serological marker of this infection (anti HIV, HCV and HBV etc.).

The residual risk of virus transmission by transfusion is only for labile blood products (PSL) [7], that is to say, essentially, cellular products, the red blood cells and platelets that cannot undergo inactivation virus like this is applied to plasma and its derivatives (socalled stable).

The purpose of this study was to estimate the residual risk among regular blood donors by serologic screening for identifying attitudes and precautions when removing the donor, and during a transfusion itself to improve blood safety, but also during the preparation of blood components and biological qualification of donations.

\section{Material and Methods}

This was a retrospective study conducted using data from the computer system of the National Blood Transfusion Centre on four three-year periods: 1998-2000, 2001-2003, 2004-2006 and 2007-2009.

It concerned 493,288 donations during these periods. These data were taken from the information processing system Progesa $4.4 \mathrm{~d}$ version of MAK-SYSTEM, and were then processed in the databases software's Acores 2000 and Excel 2000.

*Corresponding author: Adeoti Frank Mansour, Department of Medical Biochemistry, University of Cocody-Abidjan, BP V166 Abidjan, Tel: 084072 93; E-mail: giaqlabo@yahoo.fr

Received January 07, 2012; Accepted March 29, 2012; Published March 31 2012

Citation: Adeoti FM, Oyourou AO, Sirancy- Bogui L, Konate S, Sess ED (2012) Evolution of the Residual Risk of Transmitting HIV, HCV and HBV in the Blood Transfusion from 1998 to 2009 in Cote d'Ivoire. J Vaccines Vaccin 3:132. doi:10.4172/2157-7560.1000132

Copyright: (c) 2012 Adeoti FM, et al. This is an open-access article distributed under the terms of the Creative Commons Attribution License, which permits unrestricted use, distribution, and reproduction in any medium, provided the original author and source are credited. 
Citation: Adeoti FM, Oyourou AO, Sirancy- Bogui L, Konate S, Sess ED (2012) Evolution of the Residual Risk of Transmitting HIV, HCV and HBV in the Blood Transfusion from 1998 to 2009 in Cote d'Ivoire. J Vaccines Vaccin 3:132. doi:10.4172/2157-7560.1000132

Page 2 of 4

They were for regular donors, donors with at least two blood donations during the periods of study and who test negative for the markers studied (HIV, HBV and HCV) in the first donation. Incidents cases for which the gift was not transfused earlier due to the presence of other markers (ALT or anti-Hob) were excluded from analysis.

\section{Assessment of residual risk}

The method [8] is based on the calculation of incidence rates (expressed per 100000 person-years [PY]).

The incidence rate is the number of donors who have sero-converted between the different periods (1st January 1998 and 31st December 2000, 1st January 2001 and 31st December 2003, 1st January 2004 and 31st December 2006 and 1st January, 2007 and 31st December, 2009) among donors who have given blood at least twice in the same period, divided by the number of Person Years (P-Y).

The number of $\mathrm{P}-\mathrm{Y}$ is the sum of intervals in days between the first and the last donation of each donor during the period of study, divided by 365 . Residual risk = Incidence rate $\mathrm{x}$ (silent window period/365).

The window period used for the calculations were based on the 22 days data published (6-38 days) for HIV and 66 days (38-944 days) for HCV and 56 days (25-109 days) for HBs Ag [9].

\section{Biological analysis of blood donation}

The diagnosis of HIV infection for all donations was based on two repeat reactive enzyme-linked immunosorbent assays. HIV infection was confirmed and HIV-1 and HIV-2 were discriminated in another blood sample using two ELISAs.

The serums with anti-HCV antibodies were detected in ELISA. Only positive reproductible serums in the same technique were considered as positive.

Concerning the HBV, the HBs antigen (Ag HBs) was detected in ELISA. Only the reproductible positive serums were considered as positive. 1.

Reagents used during the different periods are contained in Table

\begin{tabular}{|c|c|c|c|}
\hline & VIH & VHB & $\mathrm{VHC}$ \\
\hline $1998-2000$ & $\begin{array}{l}\text { SANOFI HIV } \\
\text { UBI -HIV } \\
\text { ORGANON HIV } \\
\text { GENSGREEN HIV } \\
\text { MUREX HIV Ag/Ab } \\
\text { recombination }\end{array}$ & $\begin{array}{l}\text { MONOLISA HBS Ag } \\
\text { ULTRA } \\
\text { ORGANON Ag HBs } \\
\text { HEPANOSTIKA Ag } \\
\text { HBs }\end{array}$ & MUREX Anti HCV \\
\hline 2001-2003 & $\begin{array}{l}\text { MUREX HIV Ag/Ab } \\
\text { recombination } \\
\text { GENSGREEN HIV } \\
\text { ORGANON HIV }\end{array}$ & $\begin{array}{l}\text { MONOLISA HBS Ag } \\
\text { ULTRA } \\
\text { ORGANON Ag HBs } \\
\text { HEPANOSTIKAAg } \\
\text { HBs }\end{array}$ & $\begin{array}{l}\text { MUREX Anti HCV } \\
\text { INNOTEST HCV } \\
\text { UBI-HCV }\end{array}$ \\
\hline 2004-2006 & $\begin{array}{l}\text { GENSGREEN HIV } \\
\text { MUREX HIV Ag/Ab } \\
\text { recombination } \\
\text { INNO-LIA HIV }\end{array}$ & $\begin{array}{l}\text { MONOLISA HBS Ag } \\
\text { ULTRA } \\
\text { ORGANON Ag HBs }\end{array}$ & MUREX Anti HCV \\
\hline 2007-2009 & $\begin{array}{l}\text { MUREX HIV Ag/Ab } \\
\text { recombination } \\
\text { GENIE II HIV1/HIV2 } \\
\text { GENSGREEN ULTRA } \\
\text { HIV Ag/Ab }\end{array}$ & $\begin{array}{l}\text { MUREX Ag HBs } \\
\text { MONOLISA HBS Ag } \\
\text { ULTRA } \\
\text { HBS Ag (ARCHI- } \\
\text { TECT) }\end{array}$ & $\begin{array}{l}\text { MONOLISA Anti HCV } \\
\text { PLUS } \\
\text { MUREX Anti HCV } \\
\text { Anti HCV Reagent } \\
\text { KIT (ARCHITECT) }\end{array}$ \\
\hline
\end{tabular}

Table 1: List of reagents used according to viral markers from 1998 to 2009.
The anti-HBc antibody should have been a better marker compared to the $\mathrm{HBs} \mathrm{Ag}$ for locating all the $\mathrm{HBV}$ infections. But the high prevalence of $\mathrm{HBc} \mathrm{Ab}$ in the African adult population (almost $70 \%$ ) and the lack of the confirmation test make this marker unusable for the objective to reach; and a correction has been made in order to take the transitional nature to the HBs Ag into account.

Owing to this lack of data at the NBTC of Côte d'Ivoire, we used the published data according to which only $40 \%$ of the HBV infections are detected by the HBs Ag on the next donation [10].

\section{Results}

\section{Evolution of positive donations}

In theses four periods of 3 years, on the bases of criteria, we selected 109, 265 blood donations during 1998-2000, 2001-2003, 2004-2006 and 2007-2009. Among regular donors, the number of donations positive for HIV is the one with the largest decline over the study period of 10 years (1989-2009). It was divided by 26 .

For donations tested positive for HBs, it was more or less stable over the period and increased since 2005. In 2009, the rate is 2.4 times higher than in 2004 although it began to decline in 2008.

About donations for HCV positive after declining from 1998 to 2001, it has gradually increased from 2006 to 2009. It even doubled before falling to $68 \%$ in 2009 . Thus in 2008 , the rate of donations of anti-HCV positive was 50 times that of HIV and 4.5 times higher than that of HBs (Figure 1).

\section{Evolution of residual risk}

The residual risk of HIV has decreased over the years to be the lowest among the different residual risks in the period 2007-2009 with one per 8333 donations.

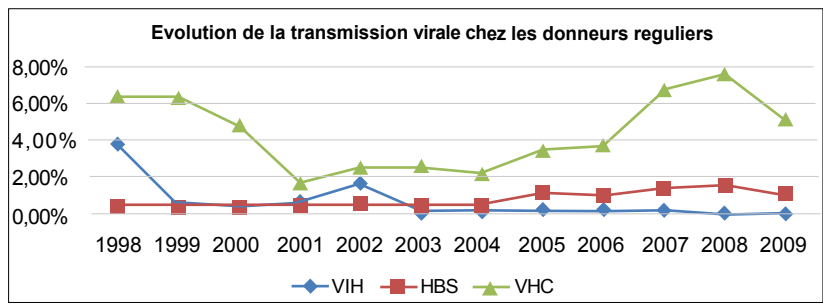

Figure 1: Evolution de la transmission virale chez les donneurs de sang bénévoles réguliers.

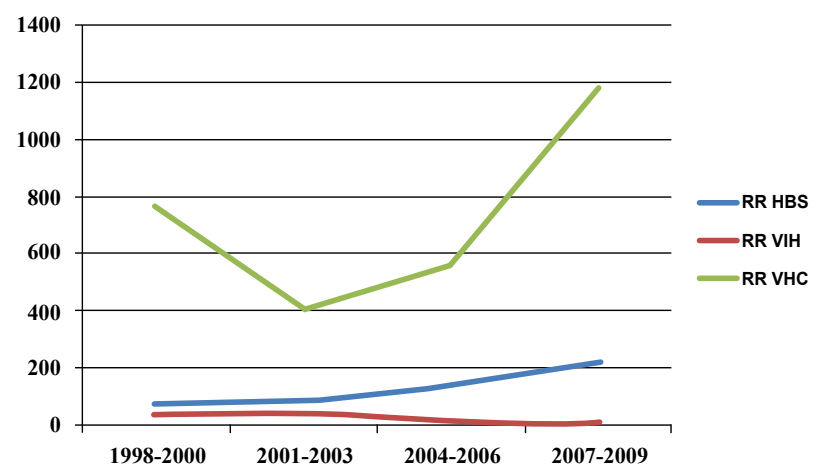

Figure 2: Risque résiduel de transmission d'infections virales pour 100000 dons entre 1998 et 2009 . 
1998-2000 2001-2003 $2004-2006 \mid 2007-2009$

\begin{tabular}{|l|l|l|l|l|l|}
\hline $\begin{array}{l}\text { Incidence rate per 105 } \\
\text { P-Y(IC à 95\%) }\end{array}$ & HIV & 583 & 782 & 284 & 201 \\
\cline { 2 - 6 } & HBV & 482 & 583 & 903 & 1429 \\
\hline & HVC & 4229 & 2238 & 3099 & 6526 \\
\hline $\begin{array}{l}\text { Estimated residual risk } \\
\text { for the period per1/n do- } \\
\text { nation (IC à 95\%) }\end{array}$ & HBV & 1351 & 2128 & 5882 & 8333 \\
\cline { 2 - 6 } & HCV & 131 & 247 & 178 & 84 \\
\hline
\end{tabular}

Table 2: HIV, HBV and HCV incidence rates and assessment of residual risk for the four periods in NBTC.

Residual risk of hepatitis $\mathrm{B}$ and $\mathrm{C}$ increased during the different periods and are respectively one per 457 donations and 1 per 85 donations over the period 2007-2009. The residual risk of HCV is 98 times that of HIV and 18 times that of hepatitis B (Table 2).

\section{Discussion}

The prevalence of hepatitis increased from $0.46 \%$ in 1998 to $1.19 \%$ in 2009 .These rate are however inferior to those found in the same establishment by Konan [11] (12.6\%) and Yohou [12] (10.5\%).

This difference can be explained by the fact that our donors are regular donors, donor loyalty to reduce HIV prevalence. This difference is also confirmed by the prevalence of HBs in $11.6 \%$ reported in blood donors in Ghana [13], mostly new donors.

The decreasing of HIV-positive donations (divided by 26) in 10 years is the result of awareness-raising and prevention of HIV infection taken in the general population and those taken to enhance the selection of donors.

An underestimation of the residual risk of the HIV transmission through blood components is due to the fact that the calculation does not take all the donations into account but only those from donors who gave their blood at least twice during the periods of 3 years.

Indeed, two French studies have shown that the incidence of HIV among new donors was twice superior [14,15]. The residual risk due to HIV was estimated to one per 2857 for the 1998-2000 period, one per 2128 for the 2001-2003 period, one per 5882 for the 2004-2006 and one per 8333 for the 2007-2009 period.

Reducing the residual risk of over half the period 2001 - 2003 to 2004-2006 is due to the introduction in 2002 of a quality approach created specifically for good laboratory practices.

The residual risk due to HIV which estimated one per 8333 donations for the 2007-2009 periods decreased significantly since it was one per 2857 donations in 1998-2000. This decreasing risk is partly due to [16]: i) The improvement of the sensitivity of screening tests, ii) The use of tests screening antigens and antibodies which shortened the window, iii) The setting of a file for regular donors, and iv) selection of donors who are part of the setting of the quality approach

The HIV transmission donations for the 2007-2009 periods (one per 8333 donations) remains superior that of Guinea (one per 8562 donations) [17]. However, this risk is higher than Touré-Fal [18] in Senegal over the period 2003-2005 was 3.5 per 100000 donations in Senegal and much less than the rate of 1 per 100 donations in 1994 Kérouedan [19] in Cote d'Ivoire.

The residual risk due to HIV which estimated the one per 5780 donations for the 2002-2004 period by Ouattara et al. [16].

These residual risks are much higher than those observed in France
(1 / 2500 000) over the periods of 2000-2002 due to the existence of stringent measures for the prevention of HIV infection taken in the general population and donor selection, but mainly because of the improved sensitivity of serological tests that have reduced the window silently passing additional 10 days to 12 days and with the use of genomic screening viral [20].

The residual risk due to HBV was estimated to one per 1351 for the 1998-2000 periods, one per 1123 for the 2001-2003 period, one per 724 for the 2004-2006 and one per 456 for the 2007-2009 period.

There is a possible overestimation for the HBV linked risk. In fact, in order to take the transient presence of HBs Ag into account, the incidence rate of $\mathrm{HBV}$ infection were extrapolated from $\mathrm{HBs} \mathrm{Ag}$ incidence rate of a factor of 2.5. Moreover the HBs Ag window period (56 days) used for the assessment of HBV residual risk was established from reagent (AUSTRIA II) which detection threshold was about 0,3 $\mathrm{ng} / \mathrm{ml}[7,10]$. But reagents used now are more sensitive because their detection threshold is inferior to $0,1 \mathrm{ng} / \mathrm{ml}$ reducing the window of about 10 days [21].

The residual risk of hepatitis B for the 2007-2009 period (one per 457 donations) is inferior to that of Guinea (1/121 donations) but higher than that of Senegal for 102.45 per 100000 donations.

$\mathrm{HCV}$, responsible for viral hepatitis, is a public health problem (according to WHO, 200 million people are infected, or 3\% of world population) [22]. La prevalence among blood donors in Côte d'Ivory is $4.2 \%$ [23].

The residual risk of hepatitis $C$ is very high in our study in 1 per 85 donations over the period 2007-2009 in spite of the measures for donor selection. It is higher than that observed in Senegal 138 to 100 000 donations.

The screening method used for the HCV enzyme immunoassay (ELISA) is very sensitive and somewhat specific: consequence obtaining false positives .hence the necessity to a more specific confirmatory test.

A prospective study was conducted in 2008, the laboratory screening of blood donations, TSSA Ivory Coast by Sekongo et al. [24] It involved a panel of $200 \mathrm{HCV}$ positive samples by ELISA repetitive. Of the 200 specimens tested at RIBA, 98 were positive. This result concurred with the Mets et al. [25] who found a prevalence of $48 \%$ in Rwanda.

Thus, to reduce the residual risk of transmission of infectious agents during blood transfusion, it is necessary to improve the effectiveness of screening techniques with highly sensitive techniques such as PCR (polymerase chain reaction) to determine the rate of infectious donations not recognized by testing [26]. But this method is of very high cost and is difficult to apply in our work environment.

\section{Conclusion}

It appears from our study that the residual risks of viral transmission during the transfusion process are important in relation to the high sero prevalence of certain viruses in blood donors.

The elevation of this residual risk of viral transmission by blood transfusion can be attributed to four factors: (i) the technical error, (ii) a viral variant not recognized by certain reagents, (iii) a grant in an infectious HIV-negative chronic carrier or (iv) a gift made in a patient recently infected ("window silent").

Also, the strengthening of blood safety should he go through a more 
Citation: Adeoti FM, Oyourou AO, Sirancy- Bogui L, Konate S, Sess ED (2012) Evolution of the Residual Risk of Transmitting HIV, HCV and HBV in the Blood Transfusion from 1998 to 2009 in Cote d'Ivoire. J Vaccines Vaccin 3:132. doi:10.4172/2157-7560.1000132

rigorous selection of donors, and awareness of these in order to avoid these various diseases by getting vaccinated for hepatitis B, protecting themselves during sex for HIV and fighting against contamination for HCV.

\section{References}

1. (2010) Document de politique nationale de transfusion sanguine, Centre National de Transfusion Sanguine", Ministère de la Santé et de l'Hygiène Publique, Côte d'Ivoire.

2. Pillonel J, Saura C, Couroucé AM (1996) Dépistage des marqueurs d'une infection par le $\mathrm{VIH}$, l'HTLV et les virus des hépatites $\mathrm{B}$ et $\mathrm{C}$ chez les donneurs de sang en France. Bull Epidemiol Hebdo 3 : 9-11.

3. Loussert-Ajaka I, Ly TD, Chaix ML, Ingrand D, Saragosti S, et al. (1994) HIV-1/ HIV-2 seronegativity in HIV-1 subtype O infected patients. Lancet 343: 13931394.

4. Martin-Rico P, Pedersen C, Skinhøj P, Nielsen C, Lindhardt BO (1995) Rapid development of AIDS in an HIV-1 antibody-negative homosexual man. AIDS 9: 95-96.

5. Elghouzzi MH, Couroucé AM, Magnius LO, Lunel F, Lapierre V (1995) Transmission of hepatitis B virus by HBV-negative blood transfusion. Lancet 346: 964.

6. Widell A, Elmud H, Persson MH, Jonsson M (1996) Transmission of hepatitis C via both erythrocyte and platelet transfusions from a single donor in serological window-phase of hepatitic C. Vox Sang 71: 55-57.

7. Couroucé AM, Pillonel J. (1997) Risque de transmission d'infections virales par transfusion de dérivés sanguins labiles". Médecine thérapeutique, Numéro 10, Décembre, Dossier: Transfusion sanguine $3: 858-862$.

8. Schreiber GB, Busch MP, Kleinman SH, Korelitz JJ (1996) The risk of transfusion-transmitted viral infections. The Retrovirus Epidemiology Donor Study. N Engl J Med 334: 1685-1690.

9. Busch MP, Lee LL, Satten GA, Henrard DR, Farzadegan H, et al. (1995) Time course of detection of viral and serologic markers preceding human immunodeficiency virus type 1 seroconversion: implications for screening of blood and tissue donors. Transfusion; 35: 91-97.

10. Couroucé AM Pillonel J (1996) Estimation du risque de transmission des virus des hepatitis $B$ et $C$ et des retrovirus humains par transfusion de dérivés sanguins labiles TBC 1: 3-8.

11. Konan KE (2000) Contribution des marqueurs sérologiques des hépatites $B$ et $\mathrm{C}$ chez les donneurs de sang au CNTS d'Abidjan. Th. Méd 2116.

12. Yohou LA (2001) Epidémiologie et caractéristique relationnelle de l'infection a $\mathrm{VIH}$ et des hépatites virales $\mathrm{B}$ et $\mathrm{C}$ chez les donneurs de sang a Abidjan (Côte d'Ivoire). Th. Med 2720.

13. Allain JP, Candotti D, Soldan K, Sarkodie F, Phelps B, et al. (2003) The risk of hepatitis B virus infection by transfusion in Kumasi, Ghana. Blood 101: 2419 2425

14. Couroucé AM (1993) HIV seropositivity in blood donors from 1990 to 1992 prevalence, estimation of residual risk of transfusion-related infections and epidemiology Rev Fr Transfus Hémobiol 36: 327-337.

15. Pillonel J, Couroucé AM, Saura C, Desenclos JC (2001) Impact of the exclusion of donors having stayed in the United Kingdom on the residual risk of HIV transmission by blood transfusion. Transfus Clin Biol 8: 85-93.

16. Ouattara H, Siransy-Bogui L, Fretz C, Diane KM, Konate S, et al. (2006) Residual risk of HIV, HVB and HCV transmission by blood transfusion between 2002 and 2004 at the Abidjan National blood center. Transfus Clin Biol 242245.

17. Loua A, Sow EM, Magassouba FB, Camara M, Baldé MA (2004) Evaluation of residual infectious risk among blood donors in National Center of Blood Transfusion in Conakry. Transfus Clin Biol 11: 98-100.

18. Touré-Fall AO, Dièye TN, Sall A, Diop M, Seck M, et al. (2009) Residual risk of transmission of HIV and HBV, in Senegalese national blood bank from 2003 to 2005. Transfus Clin Biol 16: 439-443.

19. Kerouedan D, Bontez W, Bondurand A, Abissé S, Konaté S, et al. (1994) Réflexion sur la transfusion sanguine en Afrique au temps de l'épidémie de sida. État des lieux et perspectives en Côte-d'Ivoire. Cahiers d'études et de recherches francophones / Santé. 4: 37-42.

20. Busch MP, Eble BE, Khayam-Bashi H, Heilbron D, Murphy EL, et al. (1991) Evaluation of screened blood donations for human immunodeficiency virus type 1 infection by culture and DNA amplification of pooled cells. N Engl J Med 325: 1-5.

21. Pillonel J, Laperde S (2004) Risque de la transmission du VIH, du VHC et du VHB par transfusion sanguine entre 1992 et 2002en France et dépistage génomiqueviral. Transfus Clin Bio 11: 81-84.

22. Renard F, Autier M, Domont D (2005) l'hépatite C en Belgique, commen améliorer le dépistage et la prévention? UCL - RESO Un.Educ.Santé Réf : 05-34.

23. (2008) Rapport d' activité Centre National de Transfusion Sanguine Côte d'Ivoire.

24. Sekongo YM, Kabore S, Dembele B, Yao D, Adjoumani JL, et al. (2008) Intérêt des tests de confirmation dans le diagnostic de l'hépatite virale $C$ chez les donneurs de sang a Abidjan-Côte d'ivoire , Rapport d'étude prospective CNTS, Abidjan.

25. Mets T, Smitz J, Ngend A, Haya P, Sabbe L, et al. (1995) l'hépatite C virus infection in African patient with chronic hepatitis cirrhosis and hepatocellular carcinoma: a comparative study in Niger. Ann J Trop Hyg 52: 293-296.

26. Busch MP, Eble BE, Khayam-Bashi H, Heilbron D, Murphy EL, et al. (1991) Evaluation of screened blood donations for human immunodeficiency virus type 1 infection by culture and DNA amplification of pooled cells. N Engl J Med 325: 1-5 